\title{
Review \\ How Can a Polymeric Formula Induce Remission in Crohn's Disease Patients?
}

\author{
Kawthar Boumessid ${ }^{1}$, Frederick Barreau ${ }^{1, *,+} \mathbb{D}$ and Emmanuel Mas $1,2, *,+$ \\ 1 INSERM, INRAE, ENVT, Université de Toulouse, UPS, F-31000 Toulouse, France; \\ kawthar.boumessid@inserm.fr \\ 2 Unité de Gastroentérologie, Hépatologie, Nutrition, Diabétologie et Maladies Héréditaires du Métabolisme, \\ Hôpital des Enfants, CHU de Toulouse, F-31300 Toulouse, France \\ * Correspondence: frederick.barreau@inserm.fr (F.B.); mas.e@chu-toulouse.fr (E.M.); \\ Tel.: +33-5-62-74-45-04 (F.B.); +33-5-34-55-84-45 (E.M.); Fax: +33-5-62-74-45-58 (F.B.); +33-5-34-55-85-67 (E.M.) \\ + These authors contributed equally to this work.
}

Citation: Boumessid, K.; Barreau, F.; Mas, E. How Can a Polymeric Formula Induce Remission in Crohn's Disease Patients?. Int. J. Mol. Sci. 2021, 22, 4025. https://doi.org/ $10.3390 /$ ijms 22084025

Academic Editors:

Véronique Carrière and Sophie Thenet

Received: 18 March 2021

Accepted: 12 April 2021

Published: 14 April 2021

Publisher's Note: MDPI stays neutral with regard to jurisdictional claims in published maps and institutional affiliations.

\begin{abstract}
Crohn's disease is an inflammatory bowel disease whose prevalence is increasing worldwide. Among medical strategies, dietary therapy with exclusive enteral nutrition is recommended as a first-line option, at least for children, because it induces clinical remission and mucosal healing. Modulen ${ }^{\circledR}$, a polymeric TGF- $\beta 2$ enriched formula, has good palatability and is widely used. For the first time in the literature, this review outlines and discusses the clinical outcomes obtained with this therapy, as well as the potential mechanisms of action of its compounds. It can be explained by its TGF- $\beta 2$ content, but also by its protein and lipid composition. Further well-designed studies are required to improve our knowledge and to optimize therapeutic strategies.
\end{abstract}

Keywords: Crohn's disease; inflammatory bowel disease; exclusive enteral nutrition; mucosal healing

\section{Search Strategy}

References for this review were identified on PubMed, Cochrane library, and other medical and dietary websites (Nestlé ${ }^{\circledR}$, European food safety authority, dietary guidelines, clinical trials). The terms "Modulen", "Polymeric", "enteral nutrition", "exclusive enteral nutrition", "Crohn's disease", "Inflammatory bowel disease", "mucosal healing", "steroids" were used from 1994 until 2020. Articles indicating the use of the Modulen ${ }^{\circledR}$ formula have been selected to discuss clinical remission and are summarized in Table 1. Concerning mechanisms of action, components have been discussed as well as other plausible compounds.

\section{Introduction}

Crohn's Disease

With 6.8 million cases in 2017 and an increasing worldwide prevalence of $85.1 \%$ from 1990 to 2017, inflammatory bowel disease (IBD) represents a conducive risk to issues in health, social, and economic systems [14]. Nowadays, the prevalence for Crohn's disease (CD) in North America is 319 per 100,000 persons and 322 per 100,000 persons in Europe [15]. This spectrum combines CD and ulcerative colitis, both characterized by chronic intestinal inflammation. CD can affect the whole intestinal tract, from the mouth to the anus and the lesions are patchy and transmural. The complexity of the disease principally resides in its genetic and environmental causes. Among the 37 alleles specific to $\mathrm{CD}$, the majority is related to immune reaction (nucleotide-binding oligomerization domain 2 (NOD2), ATG16L1 ... ) or mucus layer (MUC2) [16]. The mutation of NOD2 was one of the first characterized; this gene encodes for the pattern recognition receptor NOD2, described to regulate intestinal homeostasis. MUC2 gene encodes mucin 2 secreted by Goblet cells to be part of the protective mucosal layer. Concerning environmental 
factors, cigarette smoking, antibiotic use, and a high saturated fat/low fiber diet are the main ones correlated to developing $C D$. In a general manner, the pathophysiology of $C D$ is described as the outcome of an abnormal immune response, stimulated by intestinal microbiota dysbiosis. This last one consists of Gammaproteobacteria and Actinobacteria rise, as well as Bacteroides and Firmicutes decline. Even though causative explanations between microbiota and the immune system are not brought to light yet, the process is supported by intestinal permeability (IP) alterations. Indeed, increased IP along with tight junction protein modifications enhances luminal passage and thus immune stimulations. The resulting intestinal epithelium destruction displays, in turn, consequences on luminal content. A vicious circle is thus established, bringing difficulties to manage medical care. Hence, the totality of intestinal barrier compartments is disrupted: intestinal microbiota, mucosal layer, intestinal epithelium, and intestinal lymphoid tissue. Historically, the treatment of $\mathrm{CD}$ was based on anti-inflammatory drugs, i.e., corticosteroids to block the acute phase of inflammation, and on immunosuppressive drugs, like azathioprine and methotrexate, to prevent flare-up. However, although corticosteroids can reduce gastrointestinal symptoms, they have a low efficacy to achieve mucosal healing; $50 \%$ of CD patients failed to respond to corticosteroids [17]. Corticosteroids have also several side effects; they can, in particular, reduce growth velocity, which is often impaired by CD itself in children. Later on, biologics were developed to target specific inflammatory cytokines involved in IBD, like TNF $\alpha$, p40 subunit of IL-12 and IL-23, and to block lymphocyte recruitment like $\alpha 4 \beta 7$ integrin antibody. However, up to $40 \%$ of IBD patients are non-responders to tumor necrosis factor (TNF) antagonists [18]. In order to have an appropriate drug approach, it is useful to keep in mind the mechanisms of drug resistance in IBD [19] and to optimize biologic treatments [20].

Besides the drug approach, nutritional therapy by exclusive enteral nutrition (EEN) or parenteral exclusive nutrition is applied in case of inadequate caloric intake, intestinal complications, and surgery. Nowadays, gastrointestinal pediatricians prefer to use EEN rather than corticosteroids in CD children because of its efficacy in mucosal healing and growth improvement. Unlike steroids, EEN improves children's growth [21]. EEN has also the advantage to allow sufficient quantities of macronutrients and micronutrients, as well as qualitative consumption without harmful chemicals, improper cooking, and processing consequences [22]. However, the administration route and compliance are often difficult to manage for patients. Moreover, new insights suggest that some EEN ingredients might be harmful [23]. Thus far, anti-inflammatory drugs are still largely used. However, interest in EEN mushroomed these last years, but remains unclear. In this review, we focus on Modulen IBD ${ }^{\circledR}$, because it is widely used in France and other countries for $C D$ and because several clinical studies have investigated its impact on CD remission.

\section{Modulen ${ }^{\circledR}$ IBD}

Facing $C D$, there are two overriding challenges for physicians, including undernutrition, which is a common flare-up consequence among patients, and corticosteroid side effects, which can alter the growth of CD children. Modulen ${ }^{\circledR}$, allowed on the market in 2001, has been established to respond to these challenges. It is a polymeric formula for enteral or oral exclusive nutrition specifically dedicated to CD patients [24]. 
Table 1. Summary of the studies investigating Modulen ${ }^{\circledR}$.

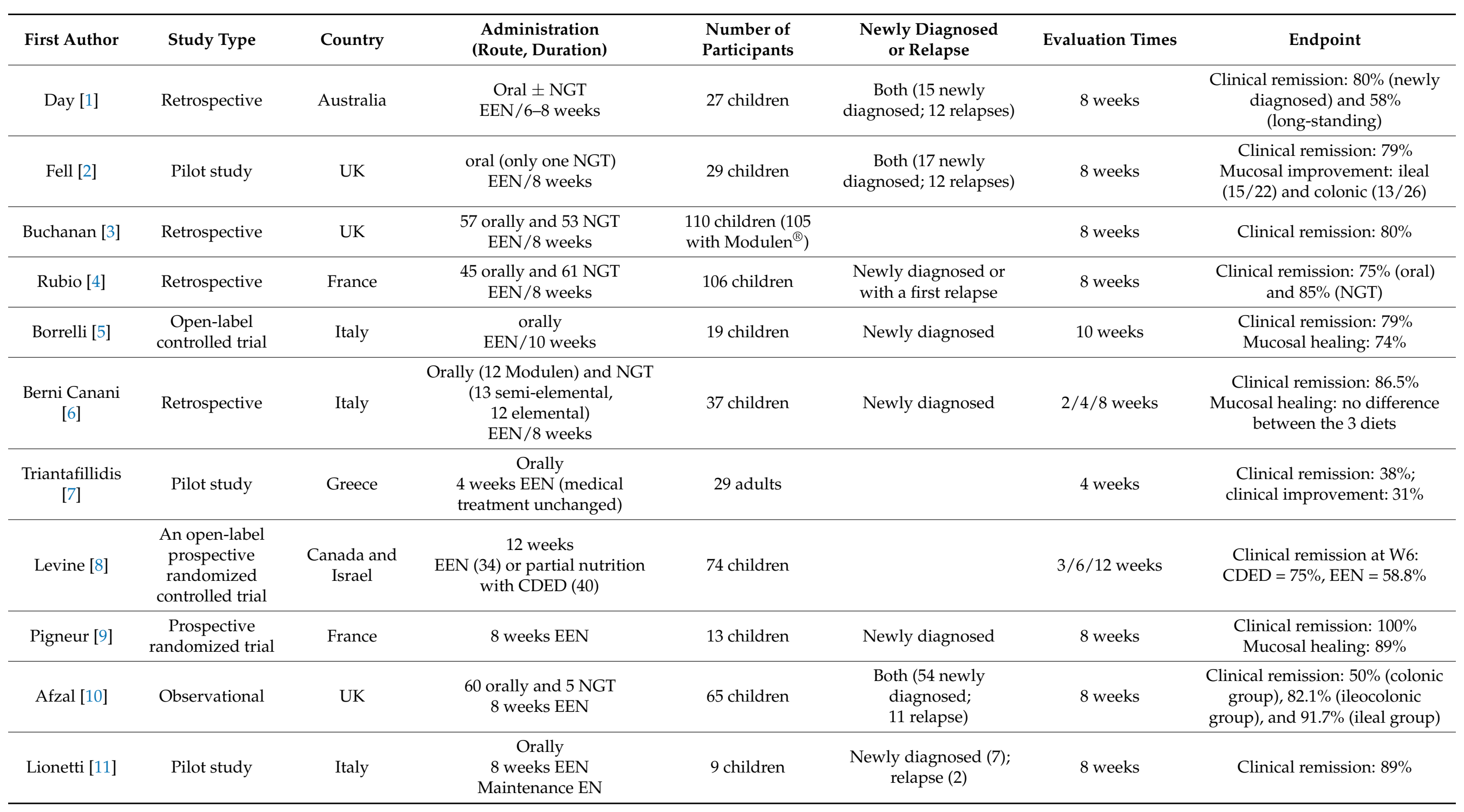


Table 1. Cont.

\begin{tabular}{|c|c|c|c|c|c|c|c|}
\hline First Author & Study Type & Country & $\begin{array}{c}\text { Administration } \\
\text { (Route, Duration) }\end{array}$ & $\begin{array}{l}\text { Number of } \\
\text { Participants }\end{array}$ & $\begin{array}{c}\text { Newly Diagnosed } \\
\text { or Relapse }\end{array}$ & Evaluation Times & Endpoint \\
\hline $\begin{array}{c}\text { Gerasimidis } \\
\text { [12] }\end{array}$ & Pilot study & UK & $\begin{array}{c}\text { Orally or NGT } \\
\text { 6-8 weeks EEN } \\
\text { Maintenance EN }\end{array}$ & 17 children & $\begin{array}{l}\text { Newly diagnosed } \\
\text { or relapse }\end{array}$ & $6-8$ weeks & $\begin{array}{l}\text { Clinical remission: } 47 \% \text {; } \\
\text { Clinical response: } 24 \%\end{array}$ \\
\hline Duncan [13] & Retrospective & UK & $\begin{array}{c}\text { Orally }(60 \%) \text { and NGT }(40 \%) \\
8 \text { weeks EN } \\
\text { Maintenance EN }\end{array}$ & 59 children & Newly diagnosed & 8 weeks & $\begin{array}{l}\text { Clinical } \\
\text { response/remission: 81\% }\end{array}$ \\
\hline
\end{tabular}




\subsection{Composition}

Modulen ${ }^{\circledR}$ is a liquid food for special medical purpose indicated during flare-ups of $C D$ patients [24]. Its exclusive use guarantees complete nutritional intake in terms of carbohydrates, lipids, and proteins with $44 \%, 42 \%$, and $14 \%$ of total energy intake respectively (Table 2). These proportions are quite in line with the European and North American dietary intake recommendations, even though the lipid fraction exceeds the upper bound of the reference intake range by seven percent $[25,26]$. However, a lipidic reference intake higher than $35 \%$ is not unhealthy, since it can take account of dietary patterns and recommendations could vary between countries [27]. Among the lipids, saturated fatty acids (SFA) are the most represented (Table 2) and can be considered as a high proportion, since the lowest consumption is the best, but half of them will lead to medium-chain fatty acids (46\% of SFA), which are crucial for Crohn's disease diet [24]. Moreover, unsaturated fatty acids are the lowest lipidic proportion (16\% of monounsaturated (MUFA) and 10\% of polyunsaturated (PUFA)) [24]. Comparing to the labelling reference intake, quantities per day of n-6 PUFA are $2.4 \mathrm{~g}$ higher and n-3 PUFA is $1.2 \mathrm{~g}$ lower. Even if these quantities are included in the reference range, it leads to an unbalanced n-6/n-3 PUFA ratio [28]. A total of 13 vitamins and 15 minerals are provided in significant quantities, but it is not the case for sodium, potassium, and fluorides. Choline, an essential nutrient, is also not provided in an adequate amount [24,29]. Modulen ${ }^{\circledR}$ is lactose, fiber, and gluten-free. Thus, carbohydrates mainly consist of glucose and sucrose. Concerning proteins, this liquid diet is 100\% casein-based [24]. Last but not least, one of the characteristics of Modulen ${ }^{\circledR}$ is its transforming growth factor $\beta 2$ (TGFß2) richness, an immunoregulatory cytokine also found in human milk and other EEN formulas (Santactiv Digest) [30,31]. This composition is adequate for the CD condition, in light of the robust clinical results obtained with Modulen ${ }^{\circledR}$.

Table 2. Composition of Modulen IBD ${ }^{\circledR}$.

\begin{tabular}{|c|c|c|c|c|c|}
\hline & $100 \mathrm{~g}$ & Per $100 \mathrm{~mL}(1.0 \mathrm{Kcal} / \mathrm{mL})$ & & $100 \mathrm{~g}$ & Per $100 \mathrm{~mL}$ (1.0 Kcal/mL) \\
\hline Energy (kcal) & 493 & 99 & Fats (g) & 23 & 4.6 \\
\hline Carbohydrates (g) & 54 & 11 & Saturated fatty acids (g) & 13 & 2.6 \\
\hline Proteins (g) & 17.5 & 3.5 & Medium chain triglycerides (g) & 6 & 1.2 \\
\hline Minerals & & & Monounsaturated fatty acids (g) & 3.9 & 0.78 \\
\hline Sodium (mg) & 170 & 34 & Polyunsaturated fatty acids (g) & 2.5 & 0.50 \\
\hline Potassium (mg) & 600 & 120 & $\alpha$ linolenic acid $(\mathrm{mg})$ & 200 & 40 \\
\hline Chloride (mg) & 365 & 73 & Linoleic acid (mg) & 2100 & 420 \\
\hline Calcium (mg) & 445 & 89 & Vitamins & & \\
\hline Phosphorus (mg) & 300 & 60 & $\mathrm{~A}(\mu \mathrm{g})$ & 410 & 82 \\
\hline Magnesium (mg) & 100 & 20 & $\mathrm{D}(\mu \mathrm{g})$ & 4.9 & 0.98 \\
\hline Iron (mg) & 5.4 & 1.1 & $\mathrm{E}(\mathrm{mg})$ & 6.5 & 1.3 \\
\hline Zinc (mg) & 4.7 & 0.94 & $K(\mu \mathrm{g})$ & 27 & 5.4 \\
\hline Copper (mg) & 0.49 & 0.098 & $\mathrm{C}(\mathrm{mg})$ & 47 & 9.4 \\
\hline Manganese (mg) & 0.98 & 0.20 & Thiamin (mg) & 0.59 & 0.12 \\
\hline Fluoride (mg) & $<0.10$ & & Riboflavin (mg) & 0.64 & 0.13 \\
\hline Selenium ( $\mu \mathrm{g})$ & 17 & 3.4 & Niacin (mg) & 5.8 & 1.2 \\
\hline Chromium $(\mu \mathrm{g})$ & 25 & 5 & B6 (mg) & 0.83 & 0.17 \\
\hline Molybdenum ( $\mu \mathrm{g})$ & 37 & 7.4 & Folic acid $(\mu \mathrm{g})$ & 120 & 24 \\
\hline Iodine $(\mu \mathrm{g})$ & 49 & 9.8 & $\mathrm{~B} 12(\mu \mathrm{g})$ & 1.6 & 0.32 \\
\hline Other nutrients & & & Biotin $(\mu \mathrm{g})$ & 16 & 3.2 \\
\hline Choline (mg) & 35 & 7 & Pantothenic acid (mg) & 2.4 & 0.48 \\
\hline $\begin{array}{l}\text { Osmolarity } \\
\text { (mOsm/L) }\end{array}$ & 290 & 290 & & & \\
\hline
\end{tabular}




\subsection{Modulen ${ }^{\circledR}$ Induces Clinical Remission}

In order to understand CD clinical management, it could be helpful to keep in mind some medical definitions. To evaluate the $\mathrm{CD}$ course, the main activity disease indexes used are $\mathrm{CD}$-activity index (CDAI) or paediatric CD activity index (PCDAI), and Harvey Bradshaw index. The score lessening refers to the clinical response. Clinical remission, however, is defined as the normalization of the activity index. At the macroscopic scale, endoscopic remission refers to a normal mucosal appearance. More precisely, the absence of visible ulcerations during endoscopy is called mucosal healing and represents the best predictive criteria of sustained remission, and thus the main clinical objective [32]. At the microscopic level, histological remission is possible, indicating a complete normalization of impaired mucosa, e.g., a deep remission.

Modulen ${ }^{\circledR}$ effectiveness to induce remission has been shown in many studies (Table 1). These studies have several limitations, while they are mainly retrospective or with no randomized control, and the endpoints were clinical remission rather than mucosal healing. Among patients treated exclusively with Modulen ${ }^{\circledR}, 65 \%$ of patients $(19 / 27$ children) have displayed a PCDAI $\leq 15$ after $6-8$ weeks [1] and 79\% (23/29 children) have reached clinical remission with a PCDAI $\leq 10$ after 8 weeks of CT32I Nestlé ${ }^{\circledR}$ formula treatment [2]. A similar rate ( $80 \%$ ) has been described by Buchanan et al. (105/114 children), who have combined both oral and nasogastric administration [3]. The mode of administration depends on patients' clinical status [33], but does not affect the clinical remission rate. After eight weeks of exclusive Modulen ${ }^{\circledR}$, oral and nasogastric administration induces $75 \%$ and $85 \%$ of clinical remission respectively $(\mathrm{PCDAI}<10)$, without any statistical difference between treatments (Table 2) [4]. Considering the severe corticosteroid side effects, numerous studies have already illustrated that exclusive nutrition has an equal efficiency to corticosteroids in children contrary in adults [34]. To our knowledge, only two studies comparing corticosteroids to exclusive nutrition have been performed by adopting the current Modulen ${ }^{\circledR}$ formula [5,6]. In the first one [5], an exclusive 10-week diet induced clinical remission and the PCDAI reduction was similar to corticosteroid treatment. However, endoscopic and histological healing was achieved at $73 \%$ in the polymeric diet group (14/19 children), significantly higher compared to $40 \%$ in the corticosteroid group (6/15). In the second one [6], PCDAI significantly decreased after eight weeks of polymeric diet compared to corticosteroids, from the second week until the third. In a long-term follow-up on mesalamine maintenance, the remission rate was longer when the induction treatment was performed by the polymeric diet, as more than $80 \%$ of individuals were in remission one year after. Another study has compared corticosteroids, cyclosporine A and enteral nutrition (EN) with an elemental diet (Flexical, Mead Johnson) or a polymeric diet (Nestlé) (Table 1) [35]. After 8 weeks of treatments, among the three patients treated with the polymeric diet, two of them had an improved histological inflammation. This outcome was similar to the elemental diet (5/6) and cyclosporine A (6/9), while it did not improve on prednisolone $(1 / 10)$. However, the number of TNF $\alpha$ secreting cells only decreased on cyclosporine A.

Besides clinical response, endoscopic and histological responses were also investigated (Table 1) [2,4-6]. The EEN treatment was effective to induce ileal and colonic endoscopic improvement as well as histological healing [2], and even mucosal healing was achieved at week 8 [4]. Only few articles highlight the capacity of EEN to reach mucosal healing [36]. While numerous studies have been performed on medicines' efficacy in mucosal healing [36], only one reported that Modulen ${ }^{\circledR}$ is more efficient to achieve mucosal healing than corticosteroids (Table 1) [9]. Although Modulen ${ }^{\circledR}$ exclusive nutrition is discerned as reliable medical management, its efficacy depending on ulceration localization, i.e., ileal/ileocolonic vs. colonic, is still a matter of controversy. On one side, the nutritional support response was not affected by the disease activity site [3,4], specifically by comparing small bowel disease and colonic disease (Table 1) [3]. On the other side, individuals with ileal and ileocolonic disease displayed a higher remission rate and improved endoscopic and histological scores [10]. 
The inflammatory status of patients was evaluated in parallel. The clinical studies demonstrate that symptoms decrease along with inflammatory serum markers such as C-reactive protein (CRP) and erythrocyte sedimentation rate (ESR) levels $[1,2,4,7,9]$, platelets [1,4], fibrinogen [7], and TNF $\alpha$ levels [2] (Table 1). Among the studies already mentioned, three of them reported a significant increase in albumin levels. Furthermore, these serological results were accompanied by reduced inflammation at the mucosal level. Ileal biopsies from CD patients pre- and post-EEN revealed a decrease of IL- $1 \beta$ and IFN- $\gamma$ mRNA, whereas colonic ones only presented IL- $1 \beta$ and CXCL-8 mRNA reduction $[2,37]$. These results attest to the anti-inflammatory effects of Modulen ${ }^{\circledR}$.

As mentioned above, the improvement of nutritional status is a primary focus. This one is commonly assessed by anthropometric parameters. More precisely, a significant amelioration of weight z-score [1,3], body weight [2,4,7], body mass index [1-3], as well as skinfold thickness, and arm circumferences [7] were described. Concerning weight gain, it seems that it is better during oral nutrition [4] (Table 1).

Exclusive nutrition can be difficult to achieve due to its lack of palatability and its partial prescription could be a potential approach. Besides, in light of the insights into food promoting inflammation, controlling qualitatively the food intake seems to be an interesting concept. In an elegant study [8], the authors have established a special CD exclusion diet (CDED) based on some compulsory foods, some allowed foods across time, and the exclusion of foods inducing inflammation or discomfort (Table 2). This CDED was accompanied by $50 \%$ of daily energy requirements as Modulen ${ }^{\circledR}$ during the first six weeks, then by $25 \%$ until week 12 , which is also called partial enteral nutrition (PEN). In contrast, other children received EEN for six weeks followed by a gradually free diet with $25 \%$ of Modulen ${ }^{\circledR}$. The results support that the exclusive diet with CDED/PEN allows significantly greater remission and tolerance than EEN. The corticosteroid-free remission rate (PCDAI < 10), respectively at week 6 and week 12 , were $75 \%$ and $75.6 \%$ for CDED/PEN combination and $59 \%$ and $45.1 \%$ for EEN. However, it should be noted that the clinical remission rate of EEN is the lowest found in the literature so far.

\subsection{Potential Mechanisms by Which Modulen ${ }^{\circledR}$ Promotes Intestinal Renewal}

There may be several ways that could explain how this formula operates (Figure 1, left panel). The liquid form is a valuable feature, since it reduces bowel movements and allows it to rest. This goes in hand with the exclusivity of the diet that can reduce dietary antigens intake and the consequent immunologic response, an intensive outcome in CD patients [38]. Concerning the composition, the lack of lactose, fibers, and gluten permits intolerant or hypersensitive patients to undergo therapy (Figure 1 left panel). Even if lactose intake has not been correlated to disease exacerbation, patients have experienced symptomatic relief after a low fermentable, oligo-, di-, mono-saccharides, and polyols (FODMAP) diet [39]. Symptoms reduction has also been self-reported by patients on a gluten-free diet, while no clinical trial has been performed yet [39]. Because fibers are incompletely digested carbohydrates, residues are decreased and thus subsequent stool frequency (Figure 1, left panel). As lactose, fiber exclusion alone has not been studied [40]. Even if numerous exclusion diets were investigated, further clinical trials examining lactose, fibers, and gluten in IBD are required.

Modulen ${ }^{\circledR}$ is different from other EN formulas mainly by its TGF- $\beta 2$ amount (Figure 1 right panel) [32]. This cytokine has intestinal benefits such as promoting IgA production, regulating tight junction proteins, and preventing Goblet cell depletion [41]. Furthermore, stimulating intestinal cells with TGF- $\beta 2$ has down-regulated CXCL-8, IL-6, and TNF $\alpha$ (Figure 1, right panel) [42]. This lessening concerns both macrophage cytokines [42] and transcriptional level modifications [42,43]. Moreover, depleting TGF- $\beta$ signalling emphasizes weight loss and inflammation in a mouse model of colitis [43]. Other studies have shown the ability of TGF- $\beta 2$ to prevent necrotizing enterocolitis [44] and mucositis [45]. Knowing that TGF- $\beta$ is also involved during restitution of mucosal healing [41], remission outcomes obtained with Modulen ${ }^{\circledR}$ could be principally explained by this cytokine 
(Figure 1, right panel). However, other components may play a potential role and should not be excluded. This is the case of protein and fatty acid contents that deserve interest.
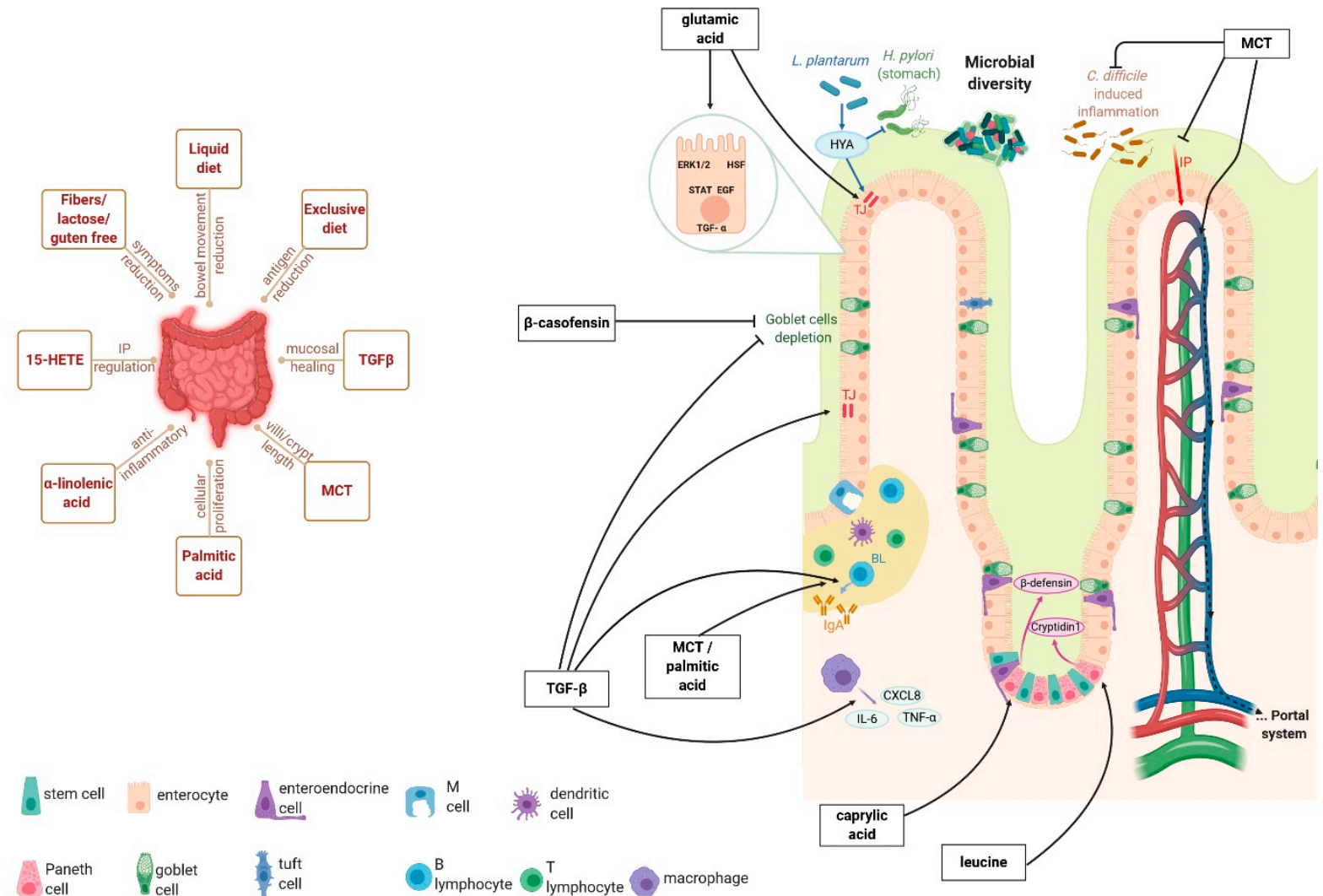

Figure 1. Mechanisms of action of Modulen ${ }^{\circledR}$ on intestinal epithelium. The left panel represents the consequences of a liquid, exclusive, and fibers/lactose/gluten-free diet, as well as TGF(transforming growth factor-beta) MCT (medium-chain triglycerides), palmitic acid, $\alpha$-linolenic acid, and 15-HETE (15-hydroxyeicosatetraenoic acid); The right panel focuses on leucine, caprylic, glutamic and palmitic acid, MCT, TGF- $\beta$, and $\beta$-casofensin.

The Modulen ${ }^{\circledR}$ formula is casein-based. This protein is significant, since it can protect TGF- $\beta 2$ from duodenal enzymatic degradation [7]. Potential beneficial effects may be due to the whole protein or to its derived peptides (Figure 1, right panel). In an ileitis model, macroscopic and microscopic lesions, and Goblet cell depletion were protected by $\beta$-casofensin [46]. The amino acid profile of casein proteins is principally rich in two essential amino acids and one non-essential [47]. The first one is leucine (from 69 to $108 \mathrm{mg} / \mathrm{g}$ ), which promotes cryptidin-1 production by Paneth cells via Slc7a8 transporter [48]. The second one is lysine (from 49 to $67 \mathrm{mg} / \mathrm{g}$ ), which has anti-inflammatory properties as demonstrated by the reduction of weight loss, disease index, and inflammatory cytokines in dextran sulfate sodium (DSS) induced colitis [49]. Finally, glutamic acid presents the highest concentration (from 218 to $239 \mathrm{mg} / \mathrm{g}$ ). This amino acid has been widely studied in the intestine and it is recognized as a principal actor in intestinal integrity (Figure 1, right panel). Not only glutamic acid can regulate proliferative, apoptotic, and inflammatory cellular pathways, but also tight junction proteins [50]. Glutamic acid can act directly on proteins such as ERK1/2, STAT, and HSF, and indirectly by enhancing growth factors' effects like EGF and TGF- $\alpha$ (Figure 1, right panel).

Some studies in the scientific literature discuss fatty acids' benefits to the intestinal mucosa. For instance, a palmitic acid-enriched diet has promoted B lymphocyte proliferation, IgA production, and cellular proliferation after a $75 \%$ bowel resection (Figure 1, right panel) [51]. Even if the whole fatty acids content of Modulen ${ }^{\circledR}$ is not specified, some of them spotlighted may contribute to clinical remission (Figure 1, right panel) [32]. 
Among them, medium-chain triglycerides (MCT), which include caproic, caprylic, capric, and lauric acid esterified, are digested and absorbed easier than long-chain triglycerides. In comparison, $\mathrm{MCT}$ are shorter carbon chain, more hydrophilic, and then does not require bile acids or cholecystokinin. Their absorption is passive and permits to gain portal system without chylomicron formation (Figure 1, right panel). MCT have shown their capacity to enhance intestinal mass and cellular proliferation at the proximal level [52], as well as villi length, crypts depth, and IgA production [53]. Additionally, studies have demonstrated that MCT can attenuate Clostridium difficile-induced inflammation [54]. More specific outcomes have been presented in in vitro studies with IPEC-J2 cells, in which caprylic acid enhanced the $\beta$-defensin $1 / 2$ secretion [55] and capric acid attenuates the oxidation, IP, and cyclophosphamide-induced inflammation (Figure 1, right panel) [56].

Modulen ${ }^{\circledR}$ dietary therapy provides essential fatty acids (Figure 1, right panel). The admitted anti-inflammatory properties of $\alpha$-linolenic acid are permitted by docosahexaenoic and eicosapentaenoic acids, along with their derived mediators (resolvins, docosatrienes, neuroprotectins) [57]. Even if the $\alpha$-linolenic acid quantity in Modulen ${ }^{\circledR}$ is low, its absorption is optimized by soya lecithin [58]. While linoleic acid is often associated with inflammation, prostaglandins E ensuing its metabolism have declined TNF $\alpha$ and IL-1 $\beta$ serum levels [57]. Other derivatives may be valuable such as 15-hydroxyeicosatetraenoic acid, whose production by intestinal glial cells is defective in CD patients [59]. The authors have shown its impact on IP regulation via zonula occludens 1 (ZO-1) expression. Another interesting fatty derivative is 10-hydroxy-cis-12-octadecenoic acid, produced by the Lactobacillus plantarum of intestinal microbiota (Figure 1 right panel) [60]. On one hand, this microbial-derived peptide improves the intestinal barrier by increasing Occludin expression; on the other hand, it alleviates Helicobacter pylori infection by inhibiting the futalosine pathway (Figure 1, right panel) [60]. Other microbial-derived peptides may be increased by Modulen ${ }^{\circledR}$ therapy. However, short-chain fatty acid production may be unlikely since the formula is fiber-free. Among butyrate-producer germs, Faecalibacterium and Anaerostipes are diminished while Ruminococcus torques is enriched (Figure 1, right panel) [36]. Additionally, the lessening of Anaerostipes and Faecalibaterium may be explained by the lack of lactose, since they are lactate-utilizing bacteria. Results about Roseburia vary [8,36], probably due to fructose malabsorption that differs between individuals. The microbiota was also enriched in Clostridium symbiosum, Clostridium ruminantium, Ruminococcus gnaves, and Clostridium hathewayi [36], in contrast to Haemophilus, Veillonella, and Prevotella [8]. Besides that, the Shannon Index and OTUs number increase demonstrate the enhancement of microbial diversity after EN (Figure 1, right panel) [36]. The bacterial composition after Modulen ${ }^{\circledR}$ s intake has returned to its pre-therapy stage. This phenomenon is associated with a regular diet upturn [8] and has been related to why EN therapy may not persist in the long term. Nonetheless, CDED has retained the consequent microbial composition, associated with a successful remission rate [8]. It is then highly plausible that the resulted bacterial composition is playing a crucial role in inducing remission, and maintaining it is a considerable approach.

\section{Future Directions}

To date, while the majority of medical treatments target the immune cell compartment of the intestinal mucosa to attenuate inflammation, Modulen ${ }^{\circledR}$ EEN leads to significant clinical remission, but also to significant mucosal healing, the most significant remission parameter by far, targeting the intestinal barrier. The fact that this formula can be orally administrated due to its palatability confers a greater tolerance and compliance for $C D$ patients. The more compliant the patient is, the greater the remission is [4]. Compliance can be affected by different factors, such as age, gender, and even beliefs [61]. To facilitate EN, allowing a regular diet is an alternative. Even if it seems to not revoke the benefits of Modulen ${ }^{\circledR}$, additionally, regular diet can depend on personal education, beliefs, habits, and temptations, and then influence in somehow the outcome. Therefore, regulated partial nutrition could be a preferable approach to a free diet to control efficacy over time [8]. 
Few studies aimed to assess the effectiveness of Modulen ${ }^{\circledR}$ in the maintenance phase of CD. Modulen ${ }^{\circledR}$ represented around $40 \%$ of daily caloric intake [11-13]. Another approach could be to perform cycles of Modulen ${ }^{\circledR}, 2$ weeks of EEN every 8 weeks, rather than daily use; the recruitment of this protocol was completed, but the data are not published yet (ClinicalTrials.gov, NCT02201693).

Numerous studies have brought to the fore nutritional, anti-inflammatory, and regenerative Modulen ${ }^{\circledR}$ properties among children, but future studies should investigate the adult case. Interestingly, remission rates are superior in newly diagnosed patients [1]. This highlights the relevance of EN and clinicians should reconsider its medical first requirement in $\mathrm{CD}$ treatment strategies. Furthermore, the dietary therapy even impacted $\mathrm{CD}$ complications. In one study, enterocutaneous fistula was diminished in $4 / 8$ patients and completely closed in one of them [7]. The available data are not sufficient to conclude about Modulen ${ }^{\circledR}$ 's impact on fistula and other complications, since these are generally exclusion criteria of clinical trials. Further well-designed studies are required to improve knowledge and to optimize therapeutic strategies.

Even though studies are contradicting each other about Modulen ${ }^{\circledR}$ efficiency on disease location $[3,4,10]$, numerous clinicians noticed that at least one ileal damage is requested. The pathophysiological differences may explain this outcome. For instance, NOD2 mutations are associated with CD with at least one lesion located in the small intestine. In view of its numerous intestinal functions, this receptor can play a significant role in EN mechanisms after microbiota recognition. This suggests that the possible modification of the intestinal microbiota by Modulen ${ }^{\circledR}$ could be primordial to induce remission. Additional studies on intestinal consequent microbiota are encouraged, both in terms of taxonomy and time. Albeit the outcome could suggest enhancing the dietary therapy with prebiotics or probiotics, one should note that the contrary could appear if the ensuing microbiota variations are highly specific.

The Modulen ${ }^{\circledR}$ composition is adequate to complete dietary intake recommendations except for choline and potassium. The first one is an acetylcholine and betaine precursor, while the second one represents an abundant electrolyte involved in fluid balance and muscle contraction regulation. Choline and potassium deficiencies may occur at the end of the Modulen ${ }^{\circledR}$ EN course like carotenoids [12]. Indeed, plasma levels of lutein, lycopene, and $\beta$-carotene were decreased, maybe causing defective defensive antioxidant mechanisms. The lack of data on nutritional deficits should be completed. These side effects could be added to minor known non-lasting side effects. However, as reported in the literature until now, the composition appears to be well balanced for CD remission and permits avoiding health status aggravation. Even if some of the ingredients may display deleterious effects, it is just a question of equilibrium with advantageous components. Aside from nutritional status, the formula compounds are almost certainly actors in Modulen ${ }^{\circledR}$ clinical efficacy. Recently, Svolos et al. proved that an exclusion diet (CD-TREAT), mimicking Modulen ${ }^{\circledR}$ composition with solid foods, leads to similar clinical, inflammatory, and intestinal microbial outcomes than EEN [62].

Other than intestinal symptoms, CD can lead to extra-intestinal ones such as bone, skin, ocular, and thromboembolic complications. These events were not investigated after EN and more specifically Modulen ${ }^{\circledR}$ therapy. This goes along with other organ consequences. The most alarming repercussion is steatosis as non-alcoholic fatty liver disease is common in IBD. Considering TGF- $\beta 2$ content, and the risk of hepatic fibrosis, hepatologists could avoid Modulen ${ }^{\circledR}$ therapy for CD patients.

Finally, in addition to gut integrity, Modulen ${ }^{\circledR}$ elements will likely benefit other organs and physiological processes allowing a well-being stage. Naturally, physical ameliorations go along with mental ones, thus achieving an effective quality of life.

In conclusion, the nutritional therapy with Modulen ${ }^{\circledR}$ is successful to enable clinical remission and probably mucosal healing. Nevertheless, the conducted studies remain scarce, and randomized controlled clinical trials are not the majority, including only a small number of patients. The therapeutic impacts on microbiota, nutritional status, and extra- 
intestinal symptoms are still lacking. To elucidate Modulen ${ }^{\circledR}$ lasting clinical efficiency, side effects, and mechanisms of action, further investigations are required.

Author Contributions: Study concept: K.B., F.B., and E.M.; drafting of the manuscript: K.B.; editing of the manuscript: K.B., F.B., and E.M. All authors have read and agreed to the published version of the manuscript.

Funding: Financial supports were provided from INSERM, DGOS (Reference Center of Rare Digestive Diseases of Toulouse University Hospital), and the patient association François Aupetit.

Conflicts of Interest: The authors declare no conflict of interest.

\begin{tabular}{|c|c|}
\hline $\mathrm{CD}$ & Crohn's disease \\
\hline CDED & CD exclusion diet \\
\hline C. difficile & Clostridium difficile \\
\hline CRP & C-reactive protein concentration \\
\hline CXCL8 & $\mathrm{C}-\mathrm{X}-\mathrm{C}$ motif ligand 8 \\
\hline DSS & Dextran sulfate sodium \\
\hline ESR & Erythrocyte sedimentation rate \\
\hline EN & Exclusive nutrition \\
\hline EEN & Exclusive enteral nutrition \\
\hline 15-HETE & 15-hydroxyeicosatetraenoic acid \\
\hline HSF & Heat Shock Factor \\
\hline HYA & 10-hydroxy-cis-12-octadecenoic acid \\
\hline IBD & Inflammatory Bowel Disease \\
\hline IP & Intestinal permeability \\
\hline IFN & Interferon \\
\hline IL & Interleukin \\
\hline IL-6 & interleukin-6 \\
\hline $\operatorname{Ig} \mathrm{A}$ & Immunoglobulin A \\
\hline L. plantarum & Lactobacillus plantarum \\
\hline $\mathrm{MCT}$ & Medium-chain triglycerides \\
\hline MUFA & Monounsaturated fatty acids \\
\hline NOD2 & Nucleotide-binding oligomerization domain 2 \\
\hline OTU & Operational taxonomic unit \\
\hline PEN & Partial enteral nutrition \\
\hline PCDAI & Pediatric clinical disease activity index \\
\hline PUFA & Polyunsaturated fatty acids \\
\hline SFA & Saturated fatty acids \\
\hline TGF & Transforming growth factor \\
\hline TGF- $\beta$ & Transforming growth factor-beta \\
\hline TGF- $\beta 2$ & Transforming growth factor $\beta 2$ \\
\hline TJ & Tight junction \\
\hline TNF & Tumor necrosis factor \\
\hline $\mathrm{TNF} \alpha$ & Tumor necrosis factor alpha \\
\hline
\end{tabular}

\section{References}

1. Day, A.S.; Whitten, K.E.; Lemberg, D.A.; Clarkson, C.; Vitug-Sales, M.; Jackson, R.; Bohane, D.T. Exclusive enteral feeding as primary therapy for Crohn's disease in Australian children and adolescents: A feasible and effective approach. J. Gastroenterol. Hepatol. 2006, 21, 1609-1614. [CrossRef]

2. Fell, J.M.; Paintin, M.; Arnaud-Battandier, F.; Beattie, R.M.; Hollis, A.; Kitching, P.; Donnet-Hughes, A.; Macdonald, T.T.; Walker-Smith, J.A. Mucosal healing and a fall in mucosal pro-inflammatory cytokine mRNA induced by a specific oral polymeric diet in paediatric Crohn's disease. Aliment. Pharmacol. Ther. 2000, 14, 281-289. [CrossRef]

3. Buchanan, E.; Gaunt, W.W.; Cardigan, T.; Garrick, V.; McGrogan, P.; Russell, R.K. The use of exclusive enteral nutrition for induction of remission in children with Crohn's disease demonstrates that disease phenotype does not influence clinical remission. Aliment. Pharmacol. Ther. 2009, 30, 501-507. [CrossRef] [PubMed] 
4. Rubio, A.; Pigneur, B.; Garnier-Lengliné, H.; Talbotec, C.; Schmitz, J.; Canioni, D.; Goulet, O.; Ruemmele, F.M. The efficacy of exclusive nutritional therapy in paediatric Crohn's disease, comparing fractionated oral vs. continuous enteral feeding. Aliment. Pharmacol. Ther. 2011, 33, 1332-1339. [CrossRef] [PubMed]

5. Borrelli, O.; Cordischi, L.; Cirulli, M.; Paganelli, M.; Labalestra, V.; Uccini, S.; Russo, P.M.; Cucchiara, S. Polymeric Diet Alone Versus Corticosteroids in the Treatment of Active Pediatric Crohn's Disease: A Randomized Controlled Open-Label Trial. Clin. Gastroenterol. Hepatol. 2006, 4, 744-753. [CrossRef] [PubMed]

6. Canani, R.B.; Terrin, G.; Borrelli, O.; Romano, M.T.; Manguso, F.; Coruzzo, A.; D’Armiento, F.; Romeo, E.F.; Cucchiara, S. Shortand long-term therapeutic efficacy of nutritional therapy and corticosteroids in paediatric Crohn's disease. Dig. Liver Dis. 2006, 38, 381-387. [CrossRef] [PubMed]

7. Triantafillidis, J.K.; Stamataki, A.; Gikas, A.; Sklavaina, M.; Mylonaki, M.; Georgopoulos, F.; Mastragelis, A.; Cheracakis, P. Beneficial effect of a polymeric feed, rich in TGF- $\beta$, on adult patients with active Crohn's disease: A pilot study. Ann. Gastroenterol. 2006, 19, 66-71.

8. Levine, A.; Wine, E.; Assa, A.; Boneh, R.S.; Shaoul, R.; Kori, M.; Cohen, S.; Peleg, S.; Shamaly, H.; On, A.; et al. Crohn's Disease Exclusion Diet Plus Partial Enteral Nutrition Induces Sustained Remission in a Randomized Controlled Trial. Gastroenterology 2019, 157, 440-450. [CrossRef] [PubMed]

9. Pigneur, B.; Lepage, P.; Mondot, S.; Schmitz, J.; Goulet, O.; Doré, J.; Ruemmele, F.M. Mucosal Healing and Bacterial Composition in Response to Enteral Nutrition Vs Steroid-based Induction Therapy-A Randomised Prospective Clinical Trial in Children With Crohn's Disease. J. Crohn's Colitis 2019, 13, 846-855. [CrossRef] [PubMed]

10. Afzal, N.A.; Davies, S.; Paintin, M.; Arnaud-Battandier, F.; Walker-Smith, J.A.; Murch, S.; Heuschkel, R.; Fell, J. Colonic Crohn's Disease in Children Does Not Respond Well to Treatment with Enteral Nutrition If the Ileum Is Not Involved. Dig. Dis. Sci. 2005, 50, 1471-1475. [CrossRef]

11. Lionetti, P.; Callegari, M.L.; Ferrari, S.; Cavicchi, M.C.; Pozzi, E.; de Martino, M.; Morelli, L. Enteral nutrition and microflora in pediatric Crohn's disease. JPEN J. Parenter. Enteral. Nutr. 2005, 29, S173-S175. [CrossRef]

12. Gerasimidis, K.; Talwar, D.; Duncan, A.; Moyes, P.; Buchanan, E.; Hassan, K.; O’Reilly, D.; McGrogan, P.; Edwards, C.A. Impact of exclusive enteral nutrition on body composition and circulating micronutrients in plasma and erythrocytes of children with active Crohn's disease. Inflamm. Bowel Dis. 2012, 18, 1672-1681. [CrossRef]

13. Duncan, H.; Buchanan, E.; Cardigan, T.; Garrick, V.; Curtis, L.; McGrogan, P.; Barclay, A.; Russell, R.K. A retrospective study showing maintenance treatment options for paediatric CD in the first year following diagnosis after induction of remission with EEN: Supplemental enteral nutrition is better than nothing! BMC Gastroenterol. 2014, 14, 50. [CrossRef] [PubMed]

14. GBD 2017 Inflammatory Bowel Disease Collaborators. The global, regional, and national burden of inflammatory bowel disease in 195 countries and territories, 1990-2017: A systematic analysis for the Global Burden of Disease Study 2017. Lancet Gastroenterol. Hepatol. 2020, 5, 17-30. [CrossRef]

15. M'Koma, A.E. Inflammatory Bowel Disease: An Expanding Global Health Problem. Clin. Med. Insights: Gastroenterol. 2013, 6, 33-47. [CrossRef]

16. Torres, J.; Mehandru, S.; Colombel, J.F.; Peyrin-Biroulet, L. Crohn's disease. Lancet 2017, 389, 1741-1755. [CrossRef]

17. Farrell, R.J.; Kelleher, D. Glucocorticoid resistance in inflammatory bowel disease. J. Endocrinol. 2003, 178, 339-346. [CrossRef] [PubMed]

18. Papamichael, K.; Gils, A.; Rutgeerts, P.; Levesque, B.G.; Vermeire, S.; Sandborn, W.J.; Casteele, N.V. Role for therapeutic drug monitoring during induction therapy with TNF antagonists in IBD: Evolution in the definition and management of primary nonresponse. Inflamm. Bowel Dis. 2015, 21, 182-197. [CrossRef] [PubMed]

19. Moreau, J.; Mas, E. Drug resistance in inflammatory bowel diseases. Curr. Opin. Pharmacol. 2015, 25, 56-61. [CrossRef] [PubMed]

20. Bourchany, A.; De Saint-Joseph, C.G.; Breton, A.; Barreau, F.; Mas, E. Optimization of biologics to reduce treatment failure in inflammatory bowel diseases. Curr. Opin. Pharmacol. 2020, 54, 51-58. [CrossRef]

21. Miele, E.; Shamir, R.; Aloi, M.; Assa, A.; Braegger, C.; Bronsky, J.; de Ridder, L.; Escher, J.C.; Hojsak, I.; Kolaček, S.; et al. Nutrition in Pediatric Inflammatory Bowel Disease: A Position Paper on Behalf of the Porto Inflammatory Bowel Disease Group of the European Society of Pediatric Gastroenterology, Hepatology and Nutrition. J. Pediatr. Gastroenterol. Nutr. 2018, 66, 687-708. [CrossRef]

22. Koithan, M.; Devika, J. New Approaches to Nutritional Therapy. J. Nurse Pract. 2010, 6, 805806. [CrossRef]

23. Logan, M.; Gkikas, K.; Svolos, V.; Nichols, B.; Milling, S.; Gaya, D.R.; Seenan, J.P.; Macdonald, J.; Hansen, R.; Ijaz, U.Z.; et al. Analysis of 61 exclusive enteral nutrition formulas used in the management of active Crohn's disease-new insights into dietary disease triggers. Aliment. Pharmacol. Ther. 2020, 51, 935-947. [CrossRef]

24. Nestle Health Science. Modulen ${ }^{\circledR}$ IBD Description. Available online: https://www.nestlehealthscience.co.uk/brands/modulen/ modulen-ibd (accessed on 14 April 2021).

25. Qin, J.; Li, R.; Raes, J.; Arumugam, M.; Burgdorf, K.S.; Manichanh, C.; Nielsen, T.; Pons, N.; Levenez, F.; Yamada, T.; et al. A human gut microbial gene catalogue established by metagenomic sequencing. Nature 2010, 464, 59-65. [CrossRef] [PubMed]

26. Xavier, R.J.; Podolsky, D.K. Unravelling the pathogenesis of inflammatory bowel disease. Nature 2007, 448, 427-434. [CrossRef] [PubMed]

27. European Food Safety Authority. Scientific opinion on dietary reference values for fats, including saturated fatty acids, polyunsaturated fatty acids, monounsaturated fatty acids, trans fatty acids and cholesterol. EFSA J. 2010, 8, 1461. 
28. Bresson, J.L.; Flynn, A.; Heinonen, M.; Hulshof, K. Scientific Opinion of the Panel on Dietetic Products, Nutrition and Allergies on a request from the Commission related to labelling reference intake values for $\mathrm{n}-3$ and $\mathrm{n}-6$ polyunsaturated fatty acids. EFSA J. 2009, 116, 1-11.

29. Ward, E. Addressing nutritional gaps with multivitamin and mineral supplements. Nutr. J. 2014, 13, 72. [CrossRef] [PubMed]

30. Gauthier, S.F.; Pouliot, Y.; Maubois, J.-L. Growth factors from bovine milk and colostrum: Composition, extraction and biological activities. Le Lait 2006, 86, 99-125. [CrossRef]

31. Triantafillidis, J.K.; Tzouvala, M.; Triantafyllidi, E. Enteral Nutrition Supplemented with Transforming Growth Factor- $\beta$, Colostrum, Probiotics, and Other Nutritional Compounds in the Treatment of Patients with Inflammatory Bowel Disease. Nutrients 2020, 12, 1048. [CrossRef] [PubMed]

32. Neurath, M.F.; Travis, S.P. Mucosal healing in inflammatory bowel diseases: A systematic review. Gut 2012, 61, 1619-1635. [CrossRef] [PubMed]

33. Forbes, A.; Escher, J.; Hébuterne, X.; Kłęk, S.; Krznaric, Z.; Schneider, S.; Shamir, R.; Stardelova, K.; Wierdsma, N.; Wiskin, A.E.; et al. ESPEN guideline: Clinical nutrition in inflammatory bowel disease. Clin. Nutr. 2017, 36, 321-347. [CrossRef]

34. Narula, N.; Dhillon, A.; Zhang, D.; Sherlock, M.E.; Tondeur, M.; Zachos, M. Enteral nutritional therapy for induction of remission in Crohn's disease. Cochrane Database Syst. Rev. 2018, 4, CD000542. [CrossRef] [PubMed]

35. Breese, E.J.; Michie, C.A.; Nicholls, S.W.; Murch, S.H.; Williams, C.B.; Domizio, P.; Walker-Smith, J.A.; Macdonald, T.T. Tumor necrosis factor $\alpha$-producing cells in the intestinal mucosa of children with inflammatory bowel disease. Gastroenterology 1994, 106, 1455-1466. [CrossRef]

36. Cholapranee, A.; Hazlewood, G.S.; Kaplan, G.G.; Peyrin-Biroulet, L.; Ananthakrishnan, A.N. Systematic review with metaanalysis: Comparative efficacy of biologics for induction and maintenance of mucosal healing in Crohn's disease and ulcerative colitis controlled trials. Aliment. Pharmacol. Ther. 2017, 45, 1291-1302. [CrossRef]

37. Fell, J.M. Control of systemic and local inflammation with transforming growth factor beta containing formulas. JPEN J. Parenter. Enteral. Nutr. 2005, 29, S126-S128. [CrossRef]

38. Kawaguchi, T.; Mori, M.; Saito, K.; Suga, Y.; Hashimoto, M.; Sako, M.; Yoshimura, N.; Uo, M.; Danjo, K.; Ikenoue, Y.; et al. Food antigen-induced immune responses in Crohn's disease patients and experimental colitis mice. J. Gastroenterol. 2015, 50, 394-405. [CrossRef] [PubMed]

39. Gibson, P.R. Use of the low-FODMAP diet in inflammatory bowel disease. J. Gastroenterol. Hepatol. 2017, 32, 40-42. [CrossRef] [PubMed]

40. Limketkai, B.N.; Iheozor-Ejiofor, Z.; Gjuladin-Hellon, T.; Parian, A.; Matarese, L.E.; Bracewell, K.; MacDonald, J.K.; Gordon, M.; Mullin, G.E. Dietary interventions for induction and maintenance of remission in inflammatory bowel disease. Cochrane Database Syst. Rev. 2019, 2, CD012839. [CrossRef] [PubMed]

41. Ihara, S.; Hirata, Y.; Koike, K. TGF-beta in inflammatory bowel disease: A key regulator of immune cells, epithelium, and the intestinal microbiota. J. Gastroenterol. 2017, 52, 777-787. [CrossRef] [PubMed]

42. Rautava, S.; Lu, L.; Nanthakumar, N.N.; Dubert-Ferrandon, A.; Walker, A.W. TGF-beta2 induces maturation of immature human intestinal epithelial cells and inhibits inflammatory cytokine responses induced via the NF-kappaB pathway. J. Pediatr. Gastroenterol. Nutr. 2012, 54, 630-688. [CrossRef]

43. Hahm, K.-B.; Im, Y.-H.; Parks, T.W.; Park, S.H.; Markowitz, S.D.; Jung, H.-Y.; Green, J.; Kim, S.J. Loss of transforming growth factor beta signalling in the intestine contributes to tissue injury in inflammatory bowel disease. Gut 2001, 49, 190-198. [CrossRef]

44. Maheshwari, A.; Kelly, D.R.; Nicola, T.; Ambalavanan, N.; Jain, S.K.; Murphy-Ullrich, J.; Athar, M.; Shimamura, M.; Bhandari, V.; Aprahamian, C.; et al. TGF-beta2 suppresses macrophage cytokine production and mucosal inflammatory responses in the developing intestine. Gastroenterology 2011, 140, 242-253. [CrossRef] [PubMed]

45. Ben-Lulu, S.; Pollak, Y.; Mogilner, J.; Bejar, J.; Coran, A.G.; Sukhotnik, I. Dietary Transforming Growth Factor-Beta 2 (TGF- $\beta 2$ ) Supplementation Reduces Methotrexate-Induced Intestinal Mucosal Injury in a Rat. PLoS ONE 2012, 7, e45221. [CrossRef] [PubMed]

46. Bessette, C.; Benoit, B.; Sekkal, S.; Bruno, J.; Estienne, M.; Léonil, J.; Ferrier, L.; Théodorou, V.; Plaisancié, P. Protective effects of $\beta$-casofensin, a bioactive peptide from bovine $\beta$-casein, against indomethacin-induced intestinal lesions in rats. Mol. Nutr. Food Res. 2016, 60, 823-833. [CrossRef] [PubMed]

47. Rafiq, S.; Huma, N.; Pasha, I.; Sameen, A.; Mukhtar, O.; Khan, M.I. Chemical Composition, Nitrogen Fractions and Amino Acids Profile of Milk from Different Animal Species. Asian-Australas. J. Anim. Sci. 2016, 29, 1022-1028. [CrossRef] [PubMed]

48. Takakuwa, A.; Nakamura, K.; Kikuchi, M.; Sugimoto, R.; Ohira, S.; Yokoi, Y.; Ayabe, T. Butyric Acid and Leucine Induce $\alpha$-Defensin Secretion from Small Intestinal Paneth Cells. Nutrients 2019, 11, 2817. [CrossRef] [PubMed]

49. Mine, Y.; Zhang, H. Anti-inflammatory Effects of Poly-L-lysine in Intestinal Mucosal System Mediated by Calcium-Sensing Receptor Activation. J. Agric. Food. Chem. 2015, 63, 10437-10447. [CrossRef]

50. Kim, M.H.; Kim, H. The Roles of Glutamine in the Intestine and Its Implication in Intestinal Diseases. Int. J. Mol. Sci. 2017, 18, 1051. [CrossRef] [PubMed]

51. Kunisawa, J.; Hashimoto, E.; Inoue, A.; Nagasawa, R.; Suzuki, Y.; Ishikawa, I.; Shikata, S.; Arita, M.; Aoki, J.; Kiyono, H. Regulation of Intestinal IgA Responses by Dietary Palmitic Acid and Its Metabolism. J. Immunol. 2014, 193, 1666-1671. [CrossRef]

52. Jenkins, A.P.; Thompson, R.P. Does the fatty acid profile of dietary fat influence its trophic effect on the small intestinal mucosa? Gut 1993, 34, 358-364. [CrossRef] [PubMed] 
53. De Keyser, K.; Dierick, N.; Kanto, U.; Hongsapak, T.; Buyens, G.; Kuterna, L.; Vanderbeke, E. Medium-chain glycerides affect gut morphology, immune- and goblet cells in post-weaning piglets: In vitro fatty acid screening with Escherichia coli and in vivo consolidation with LPS challenge. J. Anim. Physiol. Anim. Nutr. 2018, 103, 221-230. [CrossRef] [PubMed]

54. Yang, H.-T.; Chen, J.-W.; Rathod, J.; Jiang, Y.-Z.; Tsai, P.-J.; Hung, Y.-P.; Ko, W.-C.; Paredes-Sabja, D.; Huang, I.-H. Lauric Acid Is an Inhibitor of Clostridium difficile Growth in Vitro and Reduces Inflammation in a Mouse Infection Model. Front. Microbiol. 2018, 8, 2635. [CrossRef] [PubMed]

55. Wang, J.; Huang, N.; Xiong, J.; Wei, H.; Jiang, S.; Peng, J. Caprylic acid and nonanoic acid upregulate endogenous host defense peptides to enhance intestinal epithelial immunological barrier function via histone deacetylase inhibition. Int. Immunopharmacol. 2018, 65, 303-311. [CrossRef] [PubMed]

56. Lee, S.I.; Kang, K.S. Function of capric acid in cyclophosphamide-induced intestinal inflammation, oxidative stress, and barrier function in pigs. Sci. Rep. 2017, 7, 16530. [CrossRef]

57. Calder, P. Polyunsaturated fatty acids and inflammation. Biochem. Soc. Trans. 2005, 33, 423-427. [CrossRef]

58. Couëdelo, L.; Amara, S.; LeComte, M.; Meugnier, E.; Monteil, J.; Fonseca, L.; Pineau, G.; Cansell, M.; Carrière, F.; Michalski, M.C.; et al. Impact of various emulsifiers on ALA bioavailability and chylomicron synthesis through changes in gastrointestinal lipolysis. Food Funct. 2015, 6, 1726-1735. [CrossRef]

59. Pochard, C.; Coquenlorge, S.; Jaulin, J.; Cenac, N.; Vergnolle, N.; Meurette, G.; Freyssinet, M.; Neunlist, M.; Rolli-Derkinderen, M. Defects in 15-HETE Production and Control of Epithelial Permeability by Human Enteric Glial Cells From Patients with Crohn's Disease. Gastroenterology 2016, 150, 168-180. [CrossRef]

60. Saika, A.; Nagatake, T.; Kunisawa, J. Host- and Microbe-Dependent Dietary Lipid Metabolism in the Control of Allergy, Inflammation, and Immunity. Front. Nutr. 2019, 6. [CrossRef]

61. Jin, J.; Sklar, G.E.; Oh, V.M.S.; Li, S.C. Factors affecting therapeutic compliance: A review from the patient's perspective. Ther. Clin. Risk Manag. 2008, 4, 269-286.

62. Svolos, V.; Hansen, R.; Nichols, B.; Quince, C.; Ijaz, U.Z.; Papadopoulou, R.T.; Edwards, C.A.; Watson, D.; Alghamdi, A.; Brejnrod, A.; et al. Treatment of Active Crohn's Disease with an Ordinary Food-based Diet. That Replicates Exclusive Enteral Nutrition. Gastroenterology 2019, 156, 1354-1367. [CrossRef] [PubMed] 